\title{
ADIPOSE-DERIVED STEM CELLS CULTURED IN AUTOLOGOUS SERUM MAINTAIN THE CHARACTERISTICS OF MESENCHYMAL STEM CELLS
}

\author{
Ance Bogdanova, Uldis Bērziņš, Ruta Brūvere, Guḷšena Eivazova, and Tatjana Kozlovska \\ Latvian Biomedical Research and Study Centre, Rātsupītes iela 1, Rīga, LV-1067, LATVIA \\ E-mail: uldispasts@gmail.com
}

Contributed by Tatjana Kozlovska

\begin{abstract}
Human adipose tissue is known to be an attractive and readily available source of mesenchymal stem cells (MSC), which are becoming increasingly popular for application in regenerative medicine. Most of the protocols currently used for in vitro expansion of MSC include fetal bovine serum (FBS) supplementation. When MSC are cultured in such a way for clinical applications this rises concerns about immunogenicity of FBS proteins. A possible solution to this problem is the use of autologous serum (AS) instead of FBS. In this study we investigated whether adipose-derived stem cells (ADSC), cultivated in medium containing AS, maintain characteristics of MSC. The results show that the obtained ADSC were plastic adherent, rapidly dividing (doubling time $40 \pm 4$ hours), spindle-shaped cells with fibroblastoid morphology and exhibited normal karyotype. No less than 95\% of the obtained cells displayed MSC surface markers, including CD73, CD90 and CD105, but showed no expression of the hematopoietic markers CD34 and CD45. ADSC cultured in the presence of AS underwent in vitro differentiation into adipocytes, osteoblasts and chondroblasts, confirmed by Oil Red O, Alizarin Red S and Alcian Blue stains, respectively. These findings suggest that ADSC may be expanded in the AS without the loss of characteristics of MSC.
\end{abstract}

Key words: adipose-derived stem cells, autologous serum, differentiation of ADSC.

\section{INTRODUCTION}

Mesenchymal stem cells (MSC) are characterized as undifferentiated cells that possess high proliferative capacity and capability to differentiate into other cell types, for example, osteoblasts, chondroblasts, adipocytes (Pittenger et al., 1999; Romanov et al., 2005; Kern et al., 2006; Kasten et al., 2008; Secco et al., 2008), myocytes, cardiomyocytes (Wakitani et al., 1995; Fukuda, 2001; Secco et al., 2008), neurons (Kopen et al., 1999; Romanov et al., 2005) and hepatocytes (Schwartz et al., 2002; Lee et al., 2004; Taléns-Visconti et al., 2006) under the appropriate combination of growth factors and chemicals in vitro and in vivo. Although bone marrow (BM) is considered to be one of the main sources of MSC for research and clinical applications and the majority of knowledge about MSC comes from BM studies, since P. Zuk and her colleagues isolated MSC from adipose tissue, the experimental use of adipose-derived stem cells (ADSC) has increased rapidly. ADSC exhibit fibroblast-like morphology and normal diploid karyotype. They can be easily expanded in vitro, they are stable in long-term culture and are able to withstand freezing/thawing procedure without losing multilineage potential (Rodriguez et al., 2005). It has been shown that ADSC can differentiate into adipocytes, osteoblasts, chondroblasts, hepatocytes, skeletal, smooth and cardiac muscle, endothe- lial, hematopoietic, neuronal and epithelial cells (Fraser $e t$ al., 2006; McIntosh et al., 2006). Compared to BM MSC, ADSC are easier to isolate, carry lower donor site morbidity (Kakudo et al., 2007) and there are less ethical and moral concerns. Furthermore, fat reserves are highly available in humans and stem cell harvest from one milliliter of adipose tissue is 500-fold greater than that obtained from the same amount of BM (Fraser et al., 2006). At present, there have been successful attempts to use ADSC for treatment of bone defects (Lendeckel et al., 2004), Crohn's fistula (GarcíaOlmo et al., 2005) and soft tissue augmentation (Yoshimura et al., 2008).

In most of the studies and clinical trials the cell culture medium used for in vitro expansion of MSC has been supplemented with fetal bovine serum (FBS). The threats of prion diseases and zoonoses from the FBS supplementation are considered to be minimal (Doerr et al., 2003), but the greatest concern is the immunogenicity of FBS proteins. It has been shown that $10^{8}$ MSC grown in the medium supplemented with $20 \%$ FBS carries $7-30 \mathrm{mg}$ of FBS proteins, which can lead to autoimmune reaction against the patient's own stem cells (Spees et al., 2004). One approach to this problem could be the use of autologous serum (AS) instead of FBS. Hence the aim of our study was to use AS for cultivation and propagation of ADSC and to investigate whether 
ADSC cultured in such conditions express surface markers characteristic to MSC, and whether they can differentiate into adipocytes, osteoblasts and chondroblasts. The obtained results indicate that ADSC grown in the medium supplemented with AS satisfy the minimal criteria of MSC and differentiate into other cell types of mesodermal origin.

\section{MATERIALS AND METHODS}

Human adipose tissue from abdominal cavity, derived during planned operation, and blood were collected after consent was obtained from the patient in accordance to permit No. 12 issued by the Latvian Central Medical Ethics Committee. Blood and tissue samples were processed within 4-5 hours after collection.

Preparation of autologous serum. $50 \mathrm{ml}$ of blood was collected and allowed to clot for $2 \mathrm{~h}$ at room temperature (RT). The serum was collected, centrifuged at $1000 \mathrm{rpm}$ for 5 min, aliquoted and stored at $-20{ }^{\circ} \mathrm{C}$.

Isolation and cultivation of ADSC. To obtain a stromal vascular fraction (SVF) from adipose tissue, $2 \mathrm{ml}$ of adipose tissue was washed with phosphate-buffered saline (PBS) (GIBCO/Invitrogen), scissored and treated with $0.3 \%$ pronase (Calbiochem) for $1 \mathrm{~h}$ at RT with gentle rotation. Enzyme activity was neutralized with DMEM/F-12 medium (GOBCO/Invitrogen). The resulting mixture was centrifuged for $7 \mathrm{~min}$ at $1000 \mathrm{rpm}$ to separate mature adipocytes and connective tissue from the SVF pellet. The pellet was suspended in the remaining fluid and filtered through $40 \mu \mathrm{m}$ mesh. After repeated centrifugation for $5 \mathrm{~min}$ at $1000 \mathrm{rpm}$ the cell pellet was treated with erythrocyte lysis buffer (Sigma) for $3 \mathrm{~min}$ at $+37{ }^{\circ} \mathrm{C}$. Lysis of red blood cells was stopped with DMEM/F-12 medium. The obtained cell suspension was centrifuged as detailed above. The SVF pellet was suspended in fresh cell medium (DMEM/F-12 containing $10 \%$ of autologous serum (AS), $2 \mathrm{mM}$ L-glutamine (Invitrogen), $20 \mathrm{ng} / \mathrm{ml}$ basic fibroblast growth factor (BD Biosciences), and $100 \mathrm{u} / \mathrm{ml}: 100 \mu \mathrm{g} / \mathrm{ml}$ penicillin - streptomycin (Invitrogen)) and seeded into a $75 \mathrm{~cm}^{2}$ tissue culture flask. Cells were cultured at $+37{ }^{\circ} \mathrm{C}, 5 \% \mathrm{CO}_{2}$. The cells were washed on the next day with PBS to remove nonadherent cells. The remaining cell population was cultivated in medium (DMEM/F-12, $2 \mathrm{mM}$ L-glutamine, 20 $\mathrm{ng} / \mathrm{ml}$ basic fibroblast growth factor, and $100 \mathrm{u} / \mathrm{ml}: 100$ $\mu \mathrm{g} / \mathrm{ml}$ penicillin - streptomycin) supplemented with $10 \%$ of AS for first 10 days and 5\% of AS afterwards.

Karyotyping. Karyotyping of ADSC was performed at passage 3. The cells were treated with $10 \mu \mathrm{g} / \mathrm{ml}$ KaryoMAX Colcemid (Invitrogen) for $30 \mathrm{~min}$ at $+37{ }^{\circ} \mathrm{C}$ and detached using $0.25 \%$ trypsin/versen (GIBCO/Invitrogen) solution for $5 \mathrm{~min}$ at $+37{ }^{\circ} \mathrm{C}$. AmnioMAX II Complete Medium (GIBCO/Invitrogen) was added to inactivate the trypsin and the cell suspension was centrifuged for $5 \mathrm{~min}$ at $1000 \mathrm{rpm}$. The resulting cell pellet was exposed to pre-warmed $1 \%$ sodium citrate solution for $45 \mathrm{~min}$ at $+37{ }^{\circ} \mathrm{C}$. After centrifugation for $5 \mathrm{~min}$ at $1000 \mathrm{rpm}$ the cells were fixed three times in cold methanol/acetic acid $(3: 1)$ for $20 \mathrm{~min}$ at -20 ${ }^{\circ} \mathrm{C}$ followed by repeated centrifugation as detailed above. Three to four droplets of cell suspension in fixative were transferred to wet microscope slides, air-dried and heated for $1 \mathrm{~h}$ at $+90{ }^{\circ} \mathrm{C}$. Chromosomes were visualised by the standard GTG-banding technique using $0.005 \%$ trypsin/ phosphate buffer ( $\mathrm{pH}$ 6.8) solution for $1 \mathrm{~min}$ and $3 \%$ Giemsa stain for $5 \mathrm{~min}$. This analysis was performed in the E. Gulbis laboratory.

Immunocytochemistry. After the third passage, ADSC were plated onto eight well plastic chamber slides for immunocytochemistry. After $48 \mathrm{~h}$, the cells were washed with PBS $\left(+37^{\circ} \mathrm{C}\right)$ and blocked in a $6 \%$ BSA (Sigma)/PBS solution for $1 \mathrm{~h}$ at RT. Primary antibodies (mouse monoclonal anti-CD34 (Abcam), anti-CD45 (Millipore), antiCD73 (Invitrogen), anti-CD90 (Millipore) and anti-CD105 (Millipore)) were diluted in 1\% BSA/PBS (1:100) and incubated for $1.5 \mathrm{~h}$ at RT. After washing with $1 \% \mathrm{BSA} / \mathrm{PBS}$, secondary antibodies (anti-mouse IgG (Fab specific; FITC) (Sigma) and anti-mouse IgM (Alexa Fluor 488) (Molecular Probes/Invitrogen)) diluted in a $1 \%$ BSA/PBS (1: 200) were applied in dark for $1 \mathrm{~h}$ at RT. The cells were washed with PBS and incubated with wheat germ agglutinin (Alexa Fluor®633 conjugated) (Molecular Probes/Invitrogen) (10 $\mu \mathrm{g} / \mathrm{ml}$ ) for $10 \mathrm{~min}$ at RT. After repeated washing, the cells were fixed with $3.7 \%$ formaldehyde (Sigma) for $20 \mathrm{~min}$ at $+37{ }^{\circ} \mathrm{C}$. Cell nuclei were counterstained with DAPI (4 $\mu \mathrm{g} / \mathrm{ml}$ ) (Sigma) for $7 \mathrm{~min}$. The samples were mounted in ProLong Antifade reagent (Molecular Probes/Invitrogen) and kept in dark for $12 \mathrm{~h}$ at $+4{ }^{\circ} \mathrm{C}$. A fluorescence microscope DM 6000B (Leica) and laser scanning confocal system TCS SP2 SE (Leica) were used for the analysis of obtained samples.

In vitro differentiation of ADSC. After the third passage, ADSC were differentiated into adipocytes, osteoblasts and chondroblasts. To induce differentiation, ADSC were cultured in the specific induction medium, as detailed in a Table 1, according to the Invitrogen protocol (A10296, Version A). Noninduced cells were maintained in a control medium. Medium was changed every third or fourth day.

Adipogenic differentiation was confirmed on day 28 by intracellular accumulation of lipid-filled vacuoles stainable with Oil Red O (Sigma). Differentiated cells were fixed with $10 \%$ formaldehyde (Sigma) for $1 \mathrm{~h}$ at RT and washed with $60 \%$ isopropyl alcohol. After incubation in a $0.21 \%$ Oil Red O solution for 10 min at RT, the cells were counterstained with hematoxylin (GILL No.3, Sigma-Aldrich) for 3 $\min$.

Osteogenic differentiation was assessed on day 29 using Alizarin Red S (Fluka) to detect calcified extracellular matrix. Before staining, cells were fixed with $3.7 \%$ formaldehyde (Sigma) for $1 \mathrm{~h}$ at RT followed by staining with $2 \%$ Alizarin Red S (pH 4.1 - 4.3) for $4 \mathrm{~min}$.

For chondrogenic differentiation, the micromass culture technique was used according to Invitrogen protocol 
MEDIA SUPPLEMENTATION USED FOR in vitro DIFFERENTIATION OF ADIPOSE-DERIVED STEM CELLS

\begin{tabular}{|c|c|}
\hline Medium & \\
\hline Adipogenic & 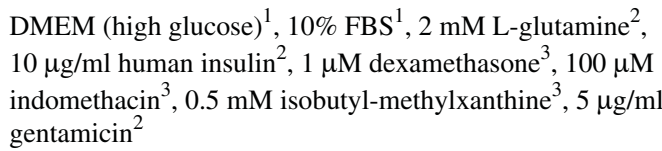 \\
\hline
\end{tabular}

Osteogenic DMEM (low glucose, without L-glutamine and phenol red) ${ }^{1}, 10 \% \mathrm{FBS}^{1}, 2 \mathrm{mM}$ L-glutamine ${ }^{2}, 10 \mathrm{mM}$ glycerol-2-phosphate ${ }^{3}, 100 \mathrm{nM}$ dexamethasone ${ }^{3}, 50 \mu \mathrm{M}$ L-ascorbic acid ${ }^{3}, 5 \mu \mathrm{g} / \mathrm{ml}$ gentamicin ${ }^{2}$

Chondrogenic DMEM (low glucose, without L-glutamine and phenol red) ${ }^{1}, 2$ mM L-glutamine ${ }^{2}$, 1x insulin-transferrin-selenium-plus ${ }^{4}, 50 \mu \mathrm{M} \mathrm{L}$-ascorbic acid ${ }^{3}, 40 \mathrm{gg} / \mathrm{ml} \mathrm{L}$-proline ${ }^{3}$, $0.1 \mu \mathrm{M}$ dexamethasone $\mathrm{e}^{3}, 10 \mathrm{ng} / \mathrm{ml}$ recombinant human TGF-ā $3^{2}, 5 \mu \mathrm{g} / \mathrm{ml}$ gentamicin ${ }^{2}$

Control DMEM (high glucose) ${ }^{1}, 10 \% \mathrm{FBS}^{1}, 2 \mathrm{mM}$ L-glutamine ${ }^{2}$, (adipogenic) $5 \mu \mathrm{g} / \mathrm{ml}$ gentamicin ${ }^{2}$

Control DMEM (low glucose) ${ }^{1}, 10 \%$ FBS $^{1}, 2$ mM L-glutamine ${ }^{2}, 5$ (osteogenic, $\mu \mathrm{g} / \mathrm{ml}$ gentamicin ${ }^{2}$

chondrogenic)

${ }^{1}$ GIBCO/Invitrogen, ${ }^{2}$ Invitrogen, ${ }^{3}$ Sigma, ${ }^{4}$ BD Biosciences

(A10296, Version A). Briefly, $10 \mu \mathrm{l}$ of cell suspension $\left(8 \times 10^{4}\right.$ cells $\left./ \mathrm{ml}\right)$ was plated into the center of each well and cells allowed to attach for $2 \mathrm{~h}$ at $+37{ }^{\circ} \mathrm{C}, 5 \% \mathrm{CO}_{2}$. Then chondrogenic differentiation or control medium was added. After 29 days, cells were stained with Alcian Blue (Sigma) at acidic $\mathrm{pH}$ to detect sulfated proteoglycans within extracellular matrix and confirm chondrogenic differentiation. Differentiated cells were fixed with $3.7 \%$ formaldehyde (Sigma) for $1 \mathrm{~h}$ at RT and then stained with $1 \%$ Alcian Blue (pH 2,5) for 30 minutes.

\section{RESULTS}

After $16 \mathrm{~h}$ of culture, a plastic-adherent cell population was observed. Most of the cells were rounded, but few were spindle-shaped cells with fibroblastoid morphology, characteristic of MSC (Zuk et al., 2001; Romanov et al., 2005; Kern et al., 2006), were also observed (Figure 1A). A day later, practically all cells exhibited typical MSC morphology (Figure 1B) and after eight days of growth, even monolayer of ADSC was formed (Figure 1C). The average cell doubling time from third to tenth passage was $40 \pm 4 \mathrm{~h}$.

To test whether the obtained ADSC had any genetic abnormalities, after third passage karyotype analysis was performed. The karyotype of normal man $(46, \mathrm{XY})$ was detected and changes in number or structure of chromosomes were not detected (Figure 2).

Analysis of MSC surface markers after third passage by immunocytochemistry showed that at least $95 \%$ of the ADSC population expressed CD73 (ecto-5'-nucleotidase), CD90 (Thy1) and CD105 (endoglin), but lacked expression of CD34 and CD45 (Figure 3), which is consistent with previous reports (Zuk et al., 2002; Seo et al., 2005; Fraser et al., 2006; Kern et al., 2006; Taléns-Visconti et al., 2006).
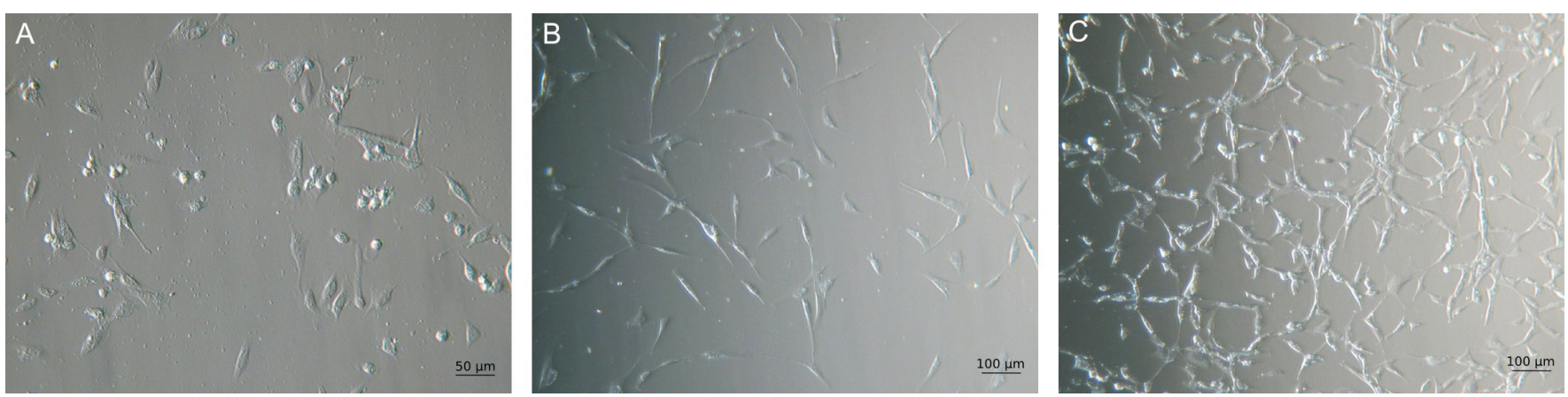

Fig. 1. Morphology of adipose-derived stem cells (ADSC). (A) ADSC on the next day after isolation. (B) ADSC two days after isolation. (C) Monolayer of ADSC eight days after isolation.
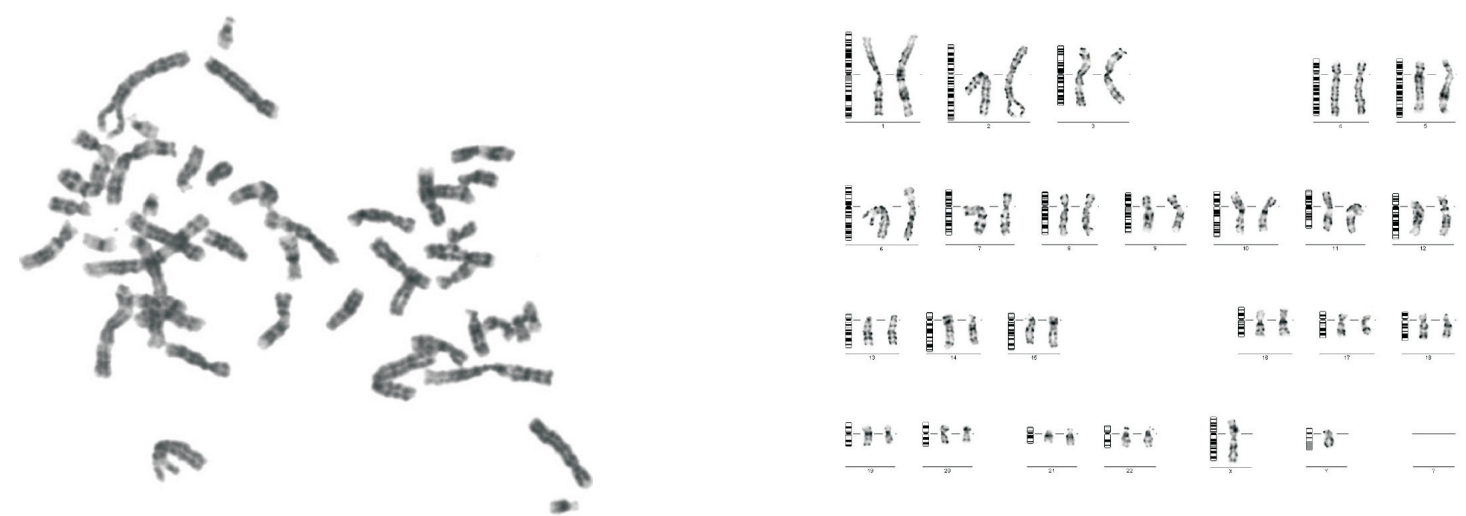

Fig. 2. Karyotype of adipose-derived stem cells after third passage. Number of metaphases analysed -16 . 

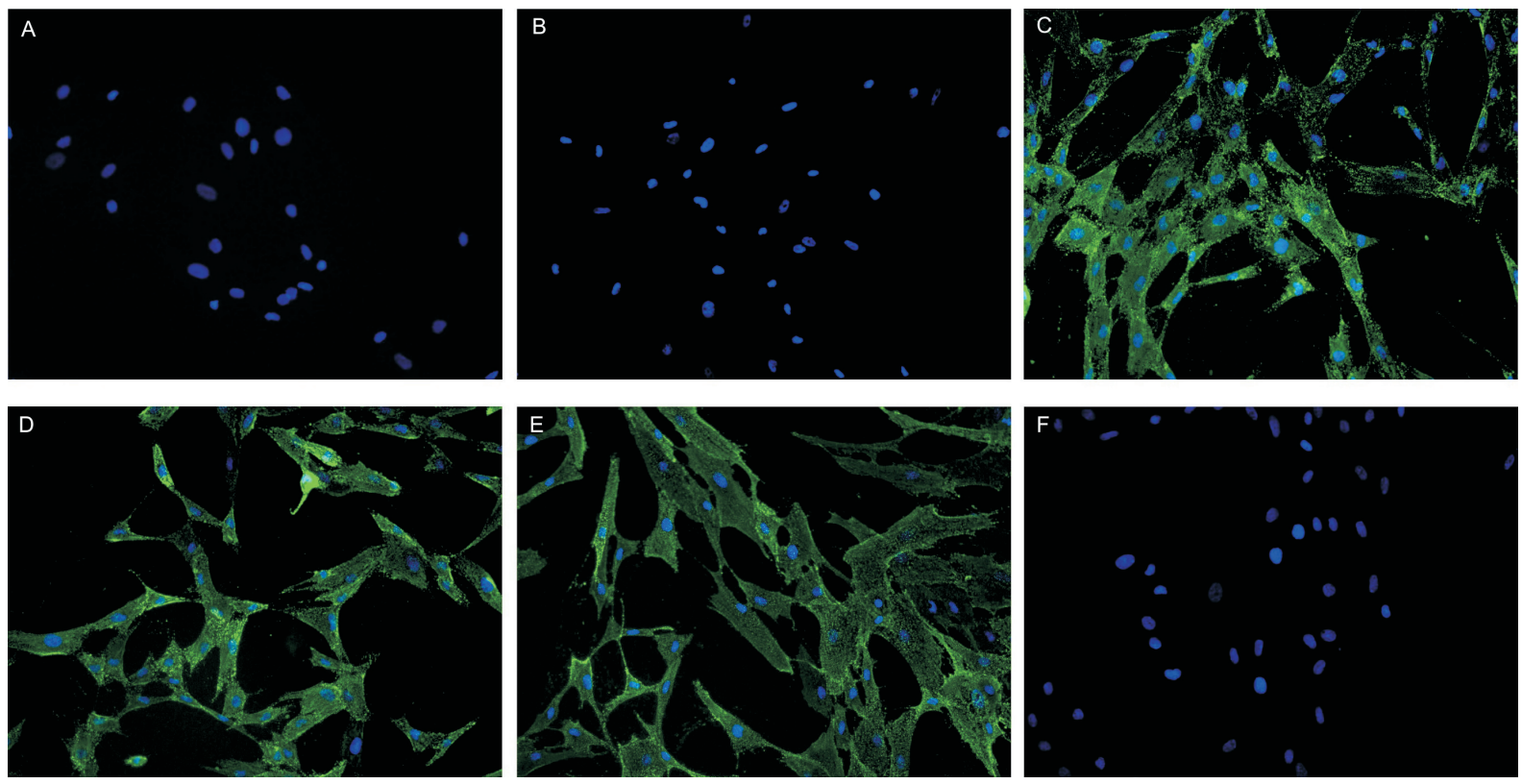

Fig. 3. Expression of adipose-derived stem cell surface markers. (A) CD34 (B) CD45 (C) CD73 (D) CD90 (E) CD105 (F) negative control, secondary antibody only. Magnification 200x.
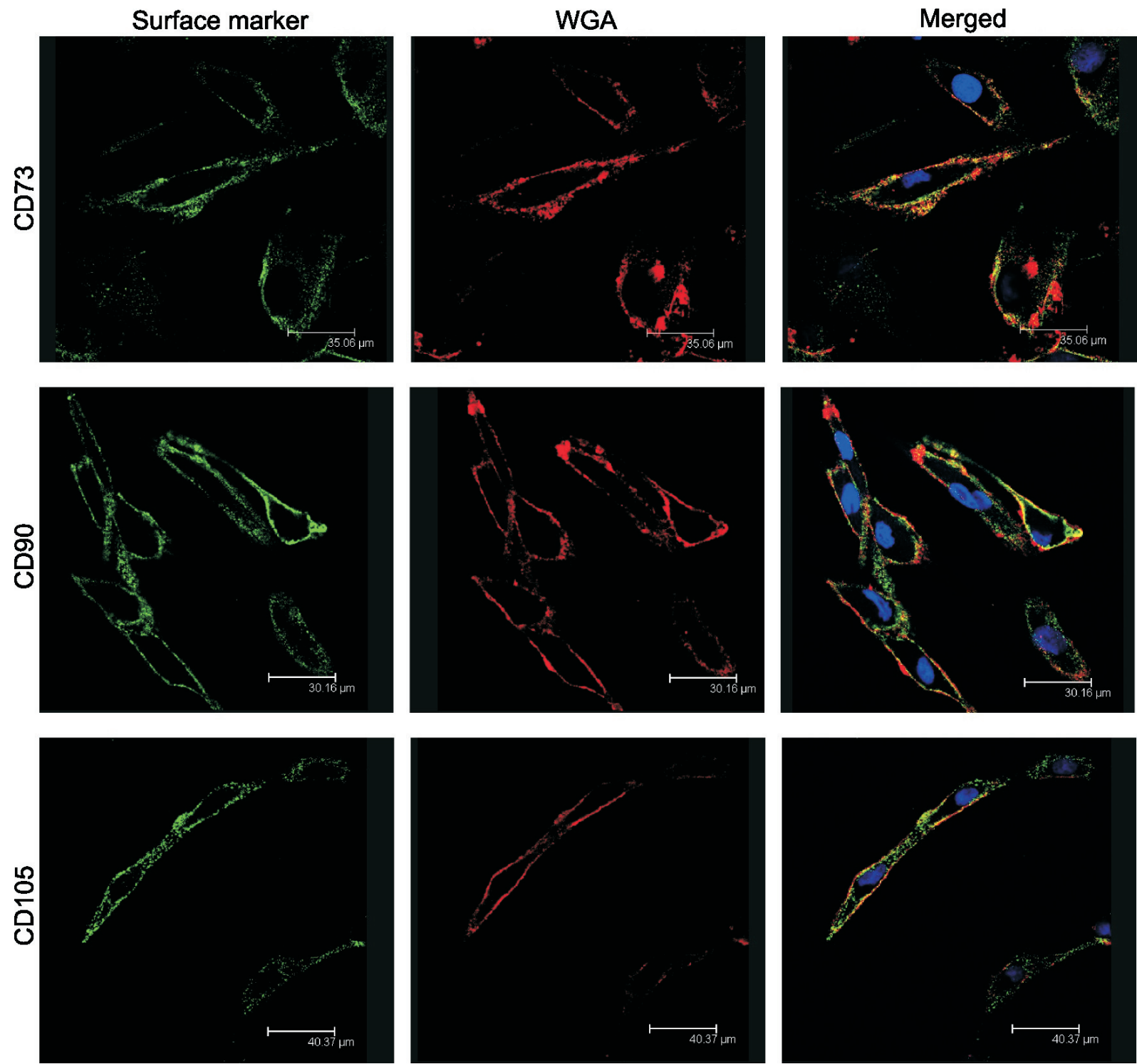

Fig. 4. Colocalization of adipose-derived stem cell surface markers CD73, CD90, CD105 and wheat germ agglutinin (WGA); analysis of confocal laser scanning microscopy. 

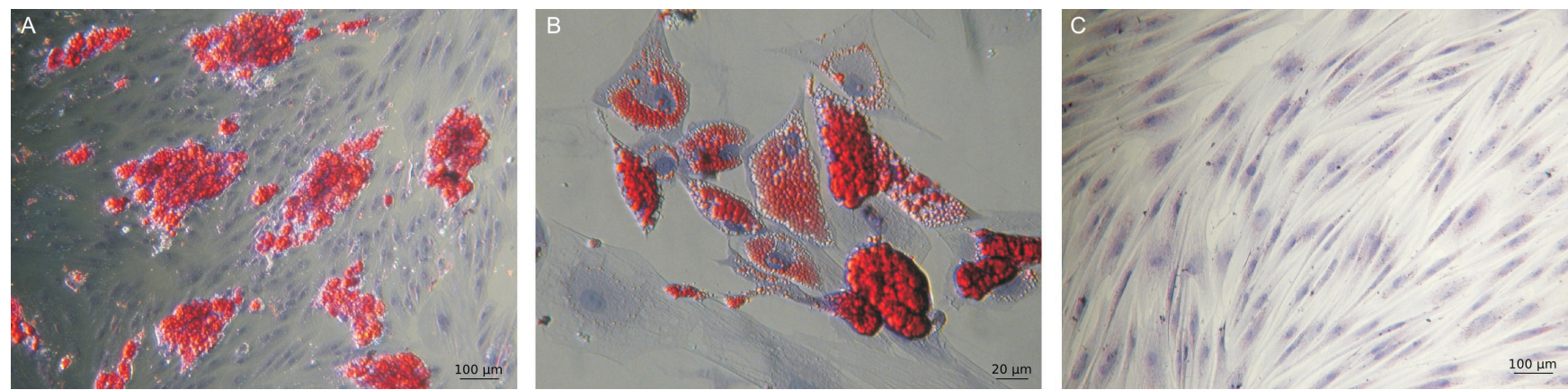

Fig. 5. Adipose-derived stem cells (ADSC) differentiated towards adipogenic lineage. (A, B) Detection of lipids with Oil red O in the differentiated cells. (C) ADSC in a control medium. The cells counterstained with hematoxylin.
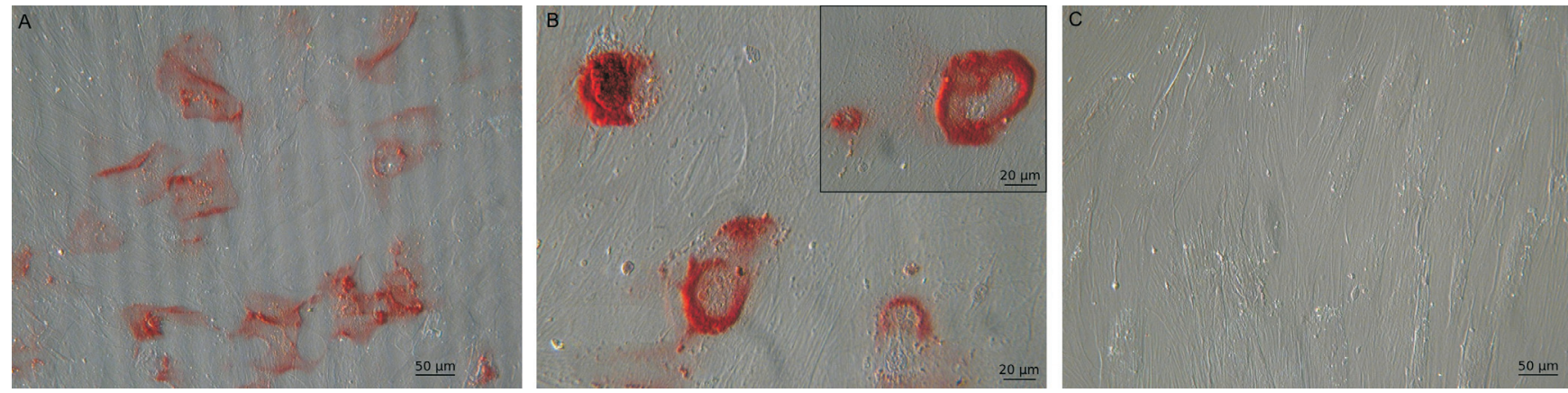

Fig. 6. Adipose-derived stem cells (ADSC) differentiated towards osteogenic lineage. (A, B) Detection of calcified extracellular matrix with Alizarin Red S in the differentiated cells. Two types of staining are shown. (C) ADSC in a control medium.
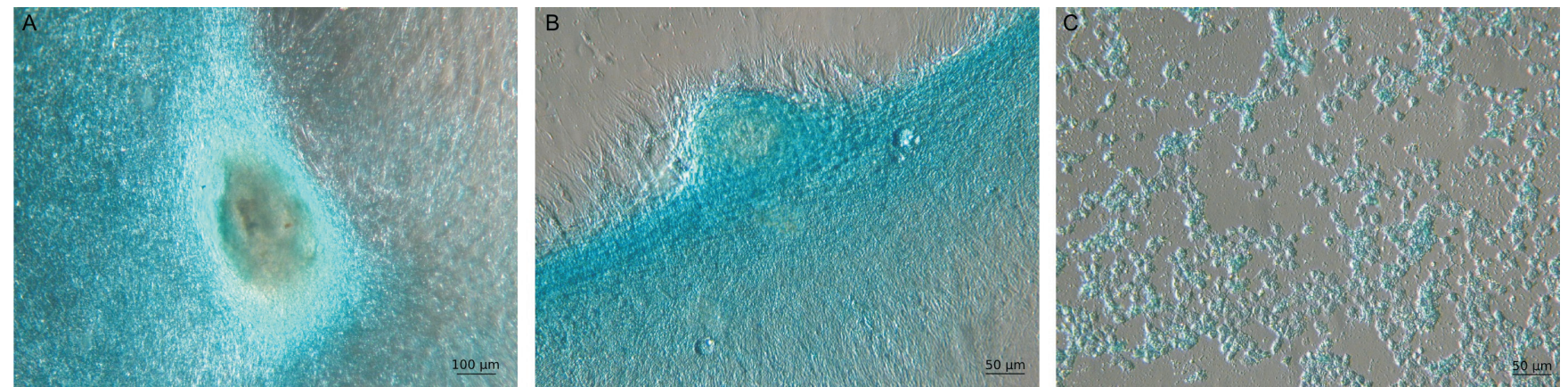

Fig. 7. Adipose-derived stem cells (ADSC) differentiated towards chondrogenic lineage. (A, B) Detection of sulfated proteoglycans with Alcian Blue in the differentiated cells. Initial and newly formed cell aggregates are shown. (C) ADSC in a control medium.

To verify that detected MSC markers are indeed on the surface of the cells, plasma membrane of ADSC was simultaneously labeled with wheat germ agglutinin (WGA) conjugated with Alexa Fluor®633. As shown in Figure 4, exact colocalisation of surface markers and WGA was observed indicating that CD73, CD90 and CD105 are found on the plasma membrane.

To test whether ADSC cultivated in a medium supplemented with AS exhibit multilineage potential, after third passage, cells were differentiated into adipocytes, osteoblasts and chondroblasts.

When ADSC were treated with adipogenic induction medium, the fibroblastoid morphology in the fraction of cells changed already after a week of differentiation. These cells were flattened and broadened and significant accumulation of intracellular lipid droplets was also observed. During dif- ferentiation, the amount of such cells and the size and the quantity of intracellular lipid-filled vacuoles increased rapidly. To confirm adipogenic differentiation after 28 days, Oil Red O stain was performed. Intracellular lipid droplets of differentiated cells accumulated Oil Red $\mathrm{O}$ indicating a mature adipocyte phenotype (Figure 5A-B). Cells cultivated in a control medium did not show signs of adipogenic differentiation (Figure 5C).

To differentiate ADSC into osteoblasts, the cells were cultivated in osteogenic medium for 29 days. To assess osteogenic differentiation, Alizarin Red $\mathrm{S}$ was used. This dye stains calcium deposits within mineralised extracellular matrix produced by osteoblasts (Tapp et al., 2009). Red staining indicated the formation of calcified extracellular matrix (Figure 6) and confirmed capability of ADSC to differentiate into osteoblasts. Two types of Alizarin Red S staining 
were observed in differentiated cells. One part of the cells had lighter and smoother staining (Figure 6A) but other cells were surrounded by dense, intensive and circular stain (Figure 6B). This difference might indicate distinct stages of differentiation. Red staining was not observed in the control cells (Figure 6C).

Chondrogenic differentiation was induced using micromass culture technique. High-density micromass culture ensure effective condensation of cells, considered to be a critical stage in the initiation of chondrogenic differentiation (Handschel et al., 2007). After 29 days of differentiation, the cells were stained with Alcian Blue under acidic conditions to detect sulphated mucopolysaccharides characteristic to extracellular matrix of chondroblasts (Lev and Spicer, 1964; Zuk et al., 2001).

Micromass culture of ADSC resulted in the formation of dense aggregates of cells. After ADSC were incubated for three days in a chondrogenic medium, new cells started to grow out of the nodule. During the chondrogenic differentiation, these cells proliferated rapidly and started to condense forming new, smaller cell aggregates. In control medium cells did not form aggregates and intense cell growth and condensation were not observed. The initial and newly formed cell aggregates in the chondrogenic medium were Alcian Blue positive (Figures 7A, 7B), indicating the presence of sulfated proteoglycans within the extracellular matrix. Weak Alcian Blue staining was also observed in the control medium, although the morphology of the cells radically differed from the cells subjected to the chondrogenic differentiation (Figure 7C).

\section{DISCUSSION}

MSC are usually cultivated in vitro in a medium supplemented with FBS. It is known that addition of FBS to the medium is important for MSC proliferation, as it provides them with many essential factors, such as hormones, substrate-attachment molecules, binding molecules for the transport and nutrients. FBS may also play a significant, but fully undefined role in the selection of MSC among the different cell types present in a primary cell culture. However, research suggests that proliferation and differentiation of MSC may depend on the quality and source of FBS (Lennon et al., 1996) and the same can be referred to the use of human AS for the expansion of MSC. Several studies have compared the effect of FBS and AS on the proliferation of bone marrow MSC. Some authors have shown that cells proliferate more efficiently in medium supplemented with FBS compared to AS (Kuznetsov et al., 2000). Others report no significant difference (Yamamoto et al., 2003). It has also been reported that MCS proliferate faster (Shahdadfar et al., 2005; Mizuno et al., 2006; Nimura et al., 2008), but differentiate more slowly in AS than in FBS (Shahdadfar et al., 2005). These contradictions may result from serum dose differences, from variation among donor sera (Nimura et al., 2008) or from distinctive harvest sites of bone marrow (Akintoye et al., 2006).
In our study, we showed that ADSC cultured in medium supplemented with 5\% AS (10\% first 10 days) could be easily and effectively propagated without the loss of specific surface markers of MSC and multipotency. The obtained ADSC exhibited fibroblast-like morphology, typical to MSC (Zuk et al., 2001; Romanov et al., 2005; Kern et al., 2006) and had normal karyotype.

Immunocytochemistry revealed that ADSC express the surface markers CD73, CD90 and CD105 but do not express CD34 and CD45, which is in accordance with other research results (Zuk et al., 2002; Seo et al., 2005; Fraser et al., 2006; Kern et al., 2006; Taléns-Visconti et al., 2006). Each of the above mentioned surface markers can be found on different types of cells and neither of them is unique to MSC. Currently, there is a lack of a specific marker that would allow to detect exclusively MSC. Therefore, a group of markers is needed to verify identity of the isolated cell population. We have analysed the batch of three positive and two negative surface markers considered to be a minimum to define human MSC (Dominici et al., 2006). Conflicting data can be found regarding the expression of CD34 by ADSC. CD34 is known as a marker of hematopoietic stem and progenitor cells but it is also expressed in vascular endothelial cells and their precursors (Fina et al., 1990). Our results show no expression of CD34 and are in accordance with previous reports (Zuk et al., 2002) while others have reported higher levels of expression of CD34 (Gronthos et al., 2001; Festy et al., 2005). This dissimilarity may be due to the epitope recognised by the anti-CD34 antibodies and stage or growth phase of the cell culture (Romanov et al., 2005; Fraser et al., 2006).

ADSC, grown in the medium supplemented with AS, differentiated into adipocytes, osteoblasts and chondroblasts in the presence of lineage-specific induction factors. Adipogenic differentiation was confirmed with Oil Red O stain, showing that at least $50 \%$ of ADSC were differentiated into mature adipocytes. Since differentiation is a gradual process and apparently does not happen equally in all cells (the size and the quantity of lipid-filled droplets are various in differentiated cells (Figure 5B)), then further cultivation in the adipogenic medium could yield in a higher efficiency of differentiation. The same may be truth about osteogenic differentiation. Alizarin Red S staining of ADSC, cultured in osteogenic medium, revealed that the cells were in different stages of differentiation - more differentiated the cell have a more calcified extracellular matrix resulting in a more pronounced stain (Figures 6A and $6 \mathrm{~B})$. Chondrogenic differentiation was determined with Alcian Blue stain, which showed the presence of sulfated mucopolysaccharides. Light blue staining was also observed in the control cells. One possible explanation for this could be the $\mathrm{pH}$ of the staining reaction. At $\mathrm{pH} 2.5$ not only sulphated, but also carboxyl groups containing mucopolysaccharides stain with Alcian Blue (Lev and Spicer, 1964). The main difference between the cells cultured in the differentiation and control media was the growth of the cells. ADSC grown in the chondrogenic medium condensed 
and formed new cell aggregates in a distinct manner, indicating the formation of a well-organized structure. In the control cells no such growth was observed.

The obtained results indicated that ADSC can be effectively cultured and expanded in the presence of AS. Such culture conditions do not influence the expression of characteristic MSC markers and ability to differentiate into adipocytes, osteoblasts and chondroblasts. The use of AS, instead of FBS, makes cultivation of MSC for therapeutic use possible without the risk of xenogeneic immune responses caused by animal proteins.

\section{ACKNOWLEDGMENTS}

This work was supported by a grant from the TOP 17-05/27 project of the Ministry of Education and Science, Republic of Latvia, by the grant from project Nr. 09.1283 of the Latvian Council of Science, by the project LU Z-971 of the University of Latvia and by ESF grant 1DP/1.1.1.2.0/09/ APIA/VIAA/150, Cilmes Šūnu Tehnologiijas Ltd.

\section{REFERENCES}

Akintoye, S.O., Lam, T., Shi, S., Brahim, J., Collins, M.T., Robey, P.G. (2006). Skeletal site-specific characterization of orofacial and iliac crest human bone marrow stromal cells in same individuals. Bone, 38(6), 758-768.

Doerr, H.W., Cinatl, J., Stürmer, M., Rabenau, H.F. (2003). Prions and orthopedic surgery. Infection, 31(3), 163-171.

Dominici, M., Le Blanc, K., Mueller, I., Slaper-Cortenbach, I., Marini, F.C., Krause, D.S., Deans, R.J., Keating, A., Prockop, D.J., Horwitz, E.M. (2006). Minimal criteria for defining multipotent mesenchymal stromal cells. The International Society for Cellular Therapy position statement. Cytotherapy, 8(4), 315-317.

Festy, F., Hoareau, L., Bes-Houtmann, S., Péquin, A.M., Gonthier, M.P., Munstun, A., Hoarau, J.J., Césari, M., Roche, R. (2005). Surface protein expression between human adipose tissue-derived stromal cells and mature adipocytes. Histochem. Cell Biol., 124(2), 113-121.

Fina, L., Molgaard, H.V., Robertson, D., Bradley, N.J., Monaghan, P., Delia, D., Sutherland, D.R., Baker, M.A., Greaves, M.F. (1990). Expression of the CD34 gene in vascular endothelial cells. Blood, 75(12), 2417-2426.

Fraser, J.K., Wulur, I., Alfonso, Z., Hedrick, M.H. (2006). Fat tissue: An underappreciated source of stem cells for biotechnology. Trends Biotechnol., 24(4), 150-154.

Fukuda, K. (2001). Development of regenerative cardiomyocytes from mesenchymal stem cells for cardiovascular tissue engineering. Artif. Organs, 25(3), 187-193.

García-Olmo, D., García-Arranz, M., Herreros, D., Pascual, I., Peiro, C., Rodríguez-Montes, J.A. (2005). A phase I clinical trial of the treatment of Crohn's fistula by adipose mesenchymal stem cell transplantation. Dis. Colon. Rectum., 48(7), 1416-1423.

Gronthos, S., Franklin, D.M., Leddy, H.A., Robey, P.G., Storms, R.W., Gimble, J.M. (2001). Surface protein characterization of human adipose tissue-derived stromal cells. J. Cell. Physiol., 189(1), 54-63.

Handschel, J.G.K., Depprich, R.A., Kübler, N.R., Wiesmann, H.P., Ommerborn, M., Meyer, U. (2007). Prospects of micromass culture technology in tissue engineering. Head Face Med., 3, 4.

Kakudo, N., Shimotsuma, A., Kusumoto, K. (2007). Fibroblast growth factor-2 stimulates adipogenic differentiation of human adipose-derived stem cells. Biochem. Biophys. Res. Commun., 359(2), 239-244.
Kasten, P., Beyen, I., Egermann, M., Suda, A.J., Moghaddam, A.A., Zimmermann, G., Liginbühl, R. (2008). Instant stem cell therapy: Characterization and concentration of human mesenchymal stem cells in vitro. Eur. Cells Mater., 16, 47-55.

Kern, S., Eichler, H., Stoeve, J., Klüter, H., Bieback, K. (2006) Comparative analysis of mesenchymal stem cells from bone marrow, umbilical cord, or adipose tissue. Stem Cells, 24(5), 1294-1301.

Kopen, G.C., Prockop, D.J., Phinney, D.G. (1999). Marrow stromal cells migrate throughout forebrain and cerebellum, and they differentiate into astrocytes after injection into neonatal mouse brains. Proc. Natl. Acad. Sci. USA, 96(19), 10711-10716.

Kuznetsov, S.A., Mankani, M.H., Robey, P.G. (2000) Effect of serum on human bone marrow stromal cells: Ex vivo expansion and in vivo bone formation. Transplantation, 70(12), 1780-1787.

Lee, K.D., Kuo, T.K.C., Whang-Peng, J., Chung, Y.F., Lin, C.T., Chou, S.H., Chen, J.R., Chen, Y.P. Lee, O.K.S. (2004). In vitro hepatic differentiation of human mesenchymal stem cells. Hepatology, 40(6), 1275-1284.

Lendeckel, S., Jödicke, A., Christophis, P., Heidinger, K., Wolff, J., Fraser, J.K., Hedrick, M.K., Berthold, L., Howaldt, H.P. (2004). Autologous stem cells (adipose) and fibrin glue used to treat widespread traumatic calvarial defects: case report. J. Craniomaxillofac. Surg., 32(6), 370-373.

Lennon, D., Haynesworth, S., Bruder, S., Jaiswal, N., Caplan, A. (1996). Human and animal mesenchymal progenitor cells from bone marrow: Identification of serum for optimal selection and proliferation. In Vitro Cell. Dev. Biol. Anim., 32(10), 602-611.

Lev, R., Spicer, S.S. (1964). Specific staining of sulphate groups with alcian blue at low pH. J. Histochem. Cytochem., 12(4), 309.

McIntosh, K., Zvonic, S., Garrett, S., Mitchell, J.B., Floyd, E., Hammill, L., Kloster, A., Halvorsen, Y.D., Ting, J.P., Storms, R.W., Goh, B., Kilroy, G., Wu, X., Gimble, J.M. (2006). The immunogenicity of human adipose-derived cells: Temporal changes in vitro. Stem Cells, 24(5), $1246-1253$.

Mizuno, N., Shiba, H., Ozeki, Y., Mouri, Y., Niitani, M., Inui, T., Hayashi, H., Suzuki, K., Tanaka, S., Kawaguchi, H., Kurihara, K. (2006). Human autologous serum obtained using a completely closed bag system as a substitute for foetal calf serum in human mesenchymal stem cell cultures. Cell Biol. Int., 30(6), 521-524.

Nimura, A., Muneta, T., Koga, H., Mochizuki, T., Suzuki, K., Makino, H., Umezawa, A., Sekiya, I. (2008). Increased proliferation of human synovial mesenchymal stem cells with autologous human serum. Comparisons with bone marrow mesenchymal stem cells and with fetal bovine serum. Arthritis Rheum., 58(2), 501-510.

Pittenger, M.F., Mackay, A.M., Beck, S.C., Jaiswal, R.K., Douglas, R., Mosca, J.D., Moorman, M.A., Simonetti, D.W., Craig, S., Marshak, D.R. (1999). Multilineage potential of adult human mesenchymal stem cells. Science, 284(5411), 143-147.

Rodriguez, A.M., Elabd, C., Amri, E.Z., Ailhaud, G., Dani, C. (2005). The human adipose tissue is a source of multipotent stem cells. Biochimie, 87(1), 125-128.

Romanov, Y.A., Darevskaya, A.N., Merzlikina, N.V., Buravkova, L.B. (2005). Mesenchymal stem cells from human bone marrow and adipose tissue: Isolation, characterization, and differentiation potentialities. Bull. Exp. Biol. Med., 140(1), 138-143.

Schwartz, R.E., Reyes, M., Koodie, L., Jiang, Y., Blackstad, M., Lund, T., Lenvik, T., Johnson, S., Hu, W.S., Verfaillie, C.M. (2002). Multipotent adult progenitor cells from bone marrow differentiate into functional hepatocyte-like cells. J. Clin. Invest., 109(10), 1291-1302.

Secco, M., Zucconi, E., Vieira, N.M., Fogaça, L.L.Q., Cerqueira, A., Carvalho, M.D.F., Jazedje, T., Okamoto, O.K., Muotri, A.R., Zatz, M. (2008). Multipotent stem cells from umbilical cord: Cord is richer than blood! Stem Cells, 26(1), 146-150.

Seo, M.J., Suh, S.Y., Bae, Y.C., Jung, J.S. (2005). Differentiation of human adipose stromal cells into hepatic lineage in vitro and in vivo. Biochem. Biophys. Res. Commun., 328(1), 258-264. 
Shahdadfar, A., Frønsdal, K., Haug, T., Reinholt, F.P., Brinchmann, J.E. (2005). In vitro expansion of human mesenchymal stem cells: Choice of serum is a determinant of cell proliferation, differentiation, gene expression, and transcriptome stability. Stem Cells, 23(9), 1357-1366.

Spees, J.L., Gregory, C.A., Singh, H., Tucker, H.A., Peister, A., Lynch, P.J., Hsu, S.C., Smith, J., Prockop, D.J. (2004). Internalized antigens must be removed to prepare hypoimmunogenic mesenchymal stem cells for cell and gene therapy. Mol. Ther., 9(5), 747-756.

Taléns-Visconti, R., Bonora, A., Jover, R., Mirabet, V., Carbonell, F., Castell, J.V., Gómez-Lechón, M.J. (2006). Hepatogenic differentiation of human mesenchymal stem cells from adipose tissue in comparison with bone marrow mesenchymal stem cells. World J. Gastroenterol., 12(36), 5834-5845.

Tapp, H., Hanley, E.N., Patt, J.C., Gruber, H.E. (2009). Adipose-derived stem cells: Characterization and current application in orthopaedic tissue repair. Exp. Biol. Med., 234(1), 1-9.

Received 30 November 2009
Wakitani, S., Saito, T., Caplan, A.I. (1995). Myogenic cells derived from rat bone marrow mesenchymal stem cells exposed to 5-azacytidine. Muscle Nerve., 18(12), 1417-1426.

Yamamoto, N., Isobe, M., Negishi, A., Yoshimasu, H., Shimokawa, H., Ohya, K., Amagasa, T., Kasugai, S. (2003). Effects of autologous serum on osteoblastic differentiation in human bone marrow cells. J. Med. Dent. Sci., 50(1), 63-69.

Yoshimura, K., Sato, K., Aoi, N., Kurita, M., Hirohi, T., Harii, K. (2008). Cell-assisted lipotransfer for cosmetic breast augmentation: Supportive use of adipose-derived stem/stromal cells. Aesthetic Plast. Surg., 32(1), 48-55.

Zuk, P.A., Zhu, M., Mizuno, H., Huang, J., Futrell, J.W., Katz, A.J., Benhaim, P., Lorenz, H.P.,Hedrick, M.H. (2001). Multilineage cells from human adipose tissue: Implications for cell-based therapies. Tissue Eng., 7(2), 211-226.

Zuk, P.A., Zhu, M., Ashjian, P., De Ugarte, D.A., Huang, J.I., Mizuno, H., Alfonso, Z.C., Fraser, J.K., Benhaim, P., Hedrick, M.H. (2002). Human adipose tissue is a source of multipotent stem cells. Mol. Biol. Cell., 13(12), 4279-4295.

\section{NO TAUKAUDIEM IZDALİTAS CILMES ŠŪNAS, KURAS KULTIVĒTAS BAROTNĒ AR AUTOLOGO SERUMU, SAGLABĀ MEZENHIMĀLO CILMES ŠŨNU İPAŠİBAS}

Cilvēka taukaudi ir viegli pieejams un vērtīgs mezenhimālo cilmes šūnu (mesenchymal stem cells, MSC) avots, un to pielietojums reǵeneratīvajā medicīnā arvien palielinās. Lielākā daḷa protokolu, kas pašlaik tiek izmantoti MSC pavairošanai in vitro, satur fetālo teḷa serumu (fetal calf serum, FCS). Šādi kultivētas MSC, kuras paredzētas klīniskiem mērkiem, rada bažas par FCS proteīnu imunogenitāti. Lai no tā izvairītos, FCS vietā var izmantot autologo serumu (AS). Šajā darbā mēs pētījām, vai no taukaudiem iegūtās cilmes šūnas (adipose-derived stem cells, ADSC), kuras tiek kultivētas barotnē ar AS, saglabā MSC īpašības. Rezultāti rāda, ka iegūtās cilmes šūnas bija plastmasas adherentas, vārpstveida šūnas ar fibroblastiem līdzīgu morfoloğiju un normālu kariotipu, tās strauji dalījās (dubultošanās laiks 40 \pm 4 stundas). Vismaz uz 95\% no iegūtajām šūnām tika detektēti MSC virsmas markieri CD73, CD90 un CD105, bet netika detektēti tādi hematopoētisko šūnu marķieri kā CD34 un CD45. ADSC, kuras kultivētas barotnē ar AS, diferenciējās in vitro par adipocītiem, osteoblastiem un hondroblastiem, ko apliecināja diferenciēto šūnu krāsošana ar Oil Red O, Alizarin Red S un Alcian Blue. Iegūtie rezultāti rāda, ka ADSC var tikt pavairotas barotnē ar AS bez MSC raksturīgo iezīmju zuduma. 